\title{
Distribution of monoamines and neuropeptides in the digestive system of juvenile Cadlina laevis (Nudibranchia)
}

\author{
O.V. Zaitseva, A.N. Shumeev \\ Zoological Institute RAS, Universitetskaya emb. 1, St.-Petersburg, 199034 Russia. E-mails: \\ ovzaitseva@inbox.ru;a-shu@yandex.ru
}

\begin{abstract}
Whole mount preparations of juvenile Cadlina laevis aged 2-4 months after hatching were examined by immunocytochemistry and histochemistry in conjunction with confocal laser microscopy to study the architecture of the digestive system, its musculature and distribution in the digestive system of catecholamine-containing, 5-HT and FMRFamide-immunoreactive (im) nervous elements. The largest number of catecholaminecontaining and FMRFamide-im nervous elements was found in the wall of the pharynx, the stomach and the digestive gland. The 5-HT-im innervation was observed primarily in the pharyngeal region of the digestive system. Catecholamine-containing and FMRFamide-im receptor cells were revealed in the oral velum around the mouth.

How to cite this article: Zaitseva O.V., Shumeev A.N. 2017. Distribution of monoamines and neuropeptides in the digestive system of juvenile Cadlina laevis (Nudibranchia) // Invert. Zool. Vol.14. No.2. P.226-233. doi: 10.15298/invertzool.14.2.18
\end{abstract}

KEY WORDS: nervous system, digestive system, musculature, gastropods, immunohistochemistry, confocal microscopy, ontogeny.

\section{Распределение моноаминов и нейропептидов в пищеварительной системе ювенильных Cadlina laevis (Nudibranchia)}

\section{О.В. Зайцева, А.Н. Шумеев}

Зоологический институт РАН, Университетская наб. 1, Санкт-Петербург, 199034 Россия. E-mails:ovzaitseva@inbox.ru ; a-shu@yandex.ru

PЕЗЮМЕ: С помощью методов иммуноцитохимии, гистохимии и конфокальной лазерной микроскопии на тотальных препаратах изучены общая организация пищеварительной системы, ее мускулатура, а также распределение в пищеварительной системе катехоламин-содержащих, серотонин- и FMRFамид-иммунореактивных (ИР) нервных элементов у ювенильных моллюсков Cadlina laevis в период с 2 до 4 месяцев после выхода из кладки. Наибольшее количество катехоламин-содержащих и FMRFамид-ИР нервных элементов было обнаружено в стенках глотки, желудка и пищеварительной железы. Серотонин-ИР иннервация наблюдалась преимущественно в глоточном отделе пищеварительной системы. Выявлены также катехоламинсодержащие и FMRFамид-ИР рецепторные клетки вокруг рта в оральном парусе моллюска. 
Как цитировать эту статью: Zaitseva O.V., Shumeev A.N. 2017. Distribution of monoamines and neuropeptides in the digestive system of juvenile Cadlina laevis (Nudibranchia) // Invert. Zool. Vol.14. No.2. P.226-233. doi: 10.15298/invertzool.14.2.18

КЛЮЧЕВЫЕ СЛОВА: нервная система, пищеварительная система, мускулатура, брюхоногие моллюски, иммуногистохимия, конфокальная микроскопия, онтогенез.

\section{Introduction}

Many species of gastropods are widely used as animal models in neurobiology studies, but because of their large body size, a complex spatial arrangement of many organs, and the presence of the shell, these gastropods cannot be studied as whole-mount preparations by confocal microscopy. These complications impose a serious challenge in gathering information on the architecture of their musculature and nerve nets containing different neurotransmitters. The study of the organization and development of the visceral nervous system in gastropods and, most notably, the nervous system of their digestive tract is of particular interest. This part of the nervous system and control of the digestive processes remain almost entirely unexplored in gastropods and the majority of other invertebrates. The gastropod digestive system is innervated primarily by the visceral ganglion (or a ganglion incorporating the visceral ganglion in nudibranchs) and by the buccal ganglia, and in nudibranchs also by supplementary gastro-oesophageal ganglia of the CNS (Bullock, Horridge, 1965; Voronezhskaya, Croll, 2016). Several gastropod species possess a high number of endocrine-like and nerve cells in the epithelia of all regions of their digestive system, with axons of these cells forming basi- and subepithelial plexuses (Zaitseva et al., 2004; Zaitseva, 2006, 2014; Zaitseva, Filimonova, 2006). As the apical poles of the majority of these cells contact the digestive cavity, they probably function as receptor cells. The wall of the digestive tract beneath the epithelium was shown to contain neurons forming microganglia and nerve plexuses (Zaitseva et al., 2009). The system of small peripheral ganglia found in the walls of the internal organs in nudibranchs was identified as the sympathetic nervous system (Bullock, Hor- ridge, 1965). Many of the regulatory cells located in the wall of the gastropod digestive tract can be cholinergic or NO-ergic, as they show acetylcholine transferase activity or NADPHdiaphorase activity, respectively (Zaitseva, Kuznetsova, 2008; Zaitseva, Markosova, 2008; Zaitseva et al., 2009). In several species of gastropods, the intestinal wall contains intraepithelial FMRFamide-im cells (Punin, 2001, Zaitseva et al., 2004).

The goal of this study was to use immunocytochemical and histochemical techniques to reveal the structure of the gastropod visceral nervous system, which regulates the functioning of the digestive system. The study was conducted on juvenile individuals of the nudibranch Cadlina laevis. Like slugs, the nudibranchs lack a shell, and their bodies are dorso-ventrally flattened. The mollusks selected for this study were almost completely formed individuals, but their size did not exceed $800 \mu \mathrm{m}$, and their bodies were almost entirely unpigmented. This made possible studying these mollusks as whole mounts by confocal microscopy and determine the spatial relationships between the musculature and nerve elements.

\section{Materials and Methods}

Egg masses of Cadlina laevis L., 1767 were collected from the White Sea near the Kartesh Biological Station of the Zoological Institute. The egg masses and hatched juveniles were maintained in the laboratory at $5-10{ }^{\circ} \mathrm{C}$. The study was conducted on the animals aged 2-4 months with a body length of $400-800 \mu \mathrm{m}$.

Catecholamines (CA) were revealed with the glyoxylic acid-induced fluorescence method (GIF) after De la Torre and Surgeon (1976), as modified by Zaitseva et al. (2015) and with the formaldehyde-glutaraldehyde fluorescence 
histochemical method (FaGlu) of Furness et al. (1977) in the modification of Voronezhskaya et al. (1999). For the GIF staining, live juveniles were incubated in the GIF medium (1 M glyoxylic acid Sigma \#G10601, 1 M sodium bicarbonate, $0.3 \mathrm{M}$ sucrose, 0.1 M HEPES, pH 7.4) for $1 \mathrm{~h}$ at $4{ }^{\circ} \mathrm{C}$, dried for $10 \mathrm{~min}$ at room temperature (RT), then for $30 \mathrm{~min}$ at $60^{\circ} \mathrm{C}$, and finally mounted in paraffin oil. For the FaGlu method, mollusks were fixed in 4\% PFA and $0.5 \%$ of glutaraldehyde in $0.01 \mathrm{M}$ PBS, $\mathrm{pH} 7.4$, for $2 \mathrm{~h}$ at RT. Then the mollusks were placed on a slide, dried for $1 \mathrm{~h}$ at RT under a ventilator, and mounted in paraffin oil. The preparations were viewed on a Leica DM 4000B fluorescent microscope (Leica E4 filter cube) and on a Leica TCS SP5 confocal microscope (405 nm laser) at the "Taxon" Research Resource Center (Zoological Institute RAS, Saint-Petersburg). Yellow fluorescence characteristic of serotonin (5HT) was absent under wide-field fluorescence microscopy. This raised the possibility that fluorescence revealed by confocal microscopy was caused by the presence of catecholamines. For this reason, we used immunocytochemical staining to visualize 5-HT.

For immunohistochemical studies, the mollusks were fixed in 2\% PFA for $30 \mathrm{~min}$ at room temperature (RT), then rinsed and permeabilized 3 times for $20 \mathrm{~min}$ in $0.3 \%$ Triton X-100 in 0.01 M PBS (PBST). Non-specific antibody binding was blocked with $2.5 \%$ bovine serum albumin in PBST (PBST-BSA), $30 \mathrm{~min}$ at RT. After that, the mollusks were incubated for 20 $30 \mathrm{~h}$ at RT in primary antibodies against FMRFamide (Immunostar, \#20091, 1:600 in PBSTBSA) or 5-HT (Immunostar, \#20080, 1:700 in PBST-BSA), rinsed in PBST-BSA $(3 \times 30 \mathrm{~min}$, RT) and incubated with secondary antibodies (24 h, RT) conjugated to Chromeo 488 (Abcam, \#ab60314, 1:500 in PBST-BSA) or Alexa Fluor 633 (Molecular Probes, \#A21071, 1:250 in PBST-BSA). To reveal muscles (F-actin), the mollusks were transferred from secondary antibodies to $22 \mathrm{nM}$ phalloidin (Alexa Fluor 546 phalloidin, Molecular Probes, \#A22283) in PBS and stained for $2.5 \mathrm{~h}$ at RT. After staining, the mollusks were rinsed in PBS $(2 \times 15 \mathrm{~min})$ and mounted in $80 \%$ glycerol in PBS. Staining specificity was checked by excluding primary antibodies. The preparations were viewed with a Leica TCS SP5 confocal microscope at the "Taxon" Research Resource Center.

\section{Results and Discussion}

The juveniles of $C$. laevis have essentially completely formed nervous and digestive systems and all major sensory organs: rhinophores, eyes, and statocysts. Their brain includes all ganglia present in adult animals. The juvenile mollusks, however, have a number of morphological differences from adults in the architecture of individual organs, their proportions, and arrangement. They still lack well-developed gills and branchial cavity, and the anus retains its ventral position underneath the notum. The pharynx is disproportionally large and occupies approximately one-third of the body volume (Figs 1, 2A). Although the pharyngeal apparatus of the juveniles has a substantial size and well-developed musculature, it is probably not yet completely functional, because the jaws and the radula are only beginning to develop.

The digestive system consists of a mouth, mouth tube, massive radular sac of the pharynx, esophagus, stomach, digestive gland (liver) and intestine ending with an anus (Figs 1,2A). The musculature in the walls of the digestive tract is composed of sparse circular and longitudinal fibers. In older juveniles, the fibers become more numerous, especially in the stomach, which has a complex shape. Continuous muscle layers (inner longitudinal and outer circular) are observed only in the radular sac (Fig. 2A, B). Three sphincters are present: around the mouth and the anus, and between the mouth tube and the radular sac (Figs 1, 2B).

FMRFamide, which is a very common neuropeptide in mollusks and other invertebrates (Punin, 2001; Voronezhskaya, Croll, 2016), is revealed in $C$. laevis in numerous peripheral nerves, in the neuropile of all CNS ganglia and in some neurons of cerebral, pleural and pedal ganglia (Fig. 2C). FMRFamide has an irregular distribution in the perikarya of most CNS neu- 


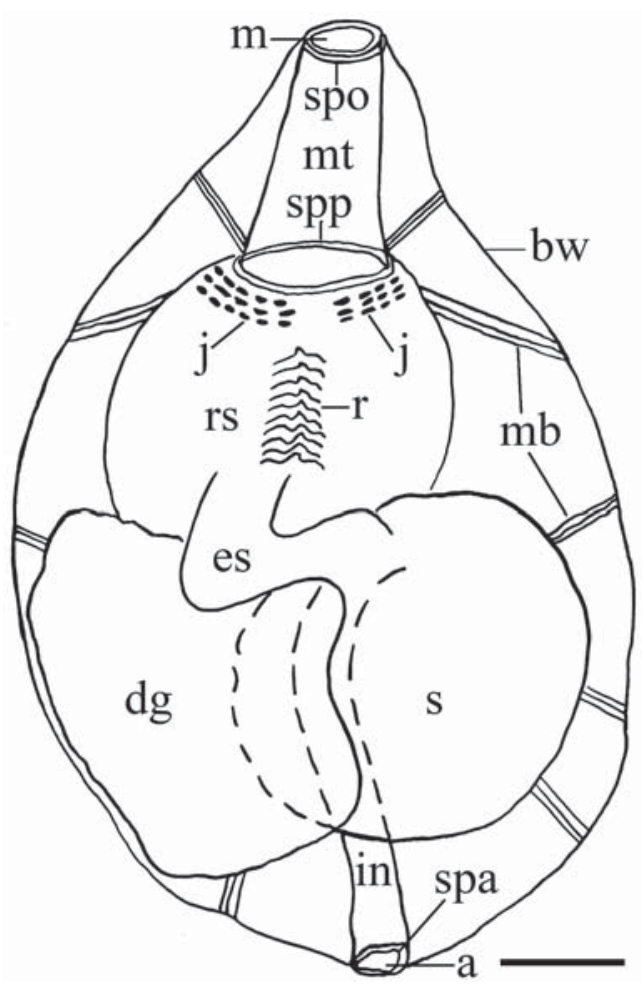

Fig. 1. Diagram of the gross anatomy of the digestive system and its location in the body of a juvenile $C$. laevis.

Abbreviations: a — anus; bw — body wall; dg digestive gland; es - oesophagus; in — intestine; $\mathrm{j}$ developing jaws; $m$ - mouth; mb - muscle bundles anchoring the digestive organs to the body wall; $\mathrm{mt}-$ mouth tube; $r$ - juvenile radula; rs - radular sac; $s$ stomach; spa — anal sphincter; spo — oral sphincter; spp — pharyngeal sphincter. Scale bar $50 \mu \mathrm{m}$.

Рис. 1. Схема общего строения пищеварительной системы и ее локализация в теле ювенильной C. laevis.

Обозначения: a — анус; bw - стенка тела; dg пищеварительная железа; es - пищевод; in - кишечник; j - формирующиеся челюсти; $\mathrm{m}$ - рот; mb мышечные пучки, прикрепляющие пищеварительные органы к стенке тела; $\mathrm{mt}$ - ротовая трубка; $\mathrm{r}$ ювенильная радула; rs - радулярный мешок; s желудок; spa - анальный сфинктер; spo - оральный сфинктер; spp - глоточный сфинктер. Масштаб 50 мкм. rons. It is often found only in the area of the axonal hillock or predominantly to one side of the nucleus in the cytoplasm of the perikaryon. In these instances, perikarya are not stained completely (Fig. 2C).

FMRFamide-im neurites are observed in double-stained (FMRFamide antibody and phalloidin) preparations in almost all parts of the digestive tract between the muscle fibers, which implicates FMRFamide in the regulation of muscle contractions in the digestive tract. FMRFamide-im is also shown for a number of neural plexuses situated directly in the digestive tract wall, especially in the wall of the stomach and the digestive gland (Fig. 2D), and for the sensory cells located around the mouth in the oral velum (Fig. 2E).

A large amount of CA is found in C. laevis in all CNS ganglia, connectives, commissures and nerves, including those innervating the digestive system (Fig. 3). CA-containing neurites innervate the musculature of major regions of the digestive tract. The innervation is especially evident in the muscular wall of the radular sac and mouth tube, including the oral and pharyngeal sphincters (Fig. 3A, B). CA-containing subepithelial receptor cells are localized around the mouth in the oral velum. Their shape and distribution are similar to those of the FMRFamid-im receptor cells (Fig. 2E). A small number of perikarya is situated in the wall of the digestive tract, mainly in the stomach and in the digestive gland (Fig. 3D). Based on these data and previously described localization of neurons in the wall of the digestive tract in some other gastropods (Bullock, Horridge, 1965), we suppose the existence of the intrinsic nervous system in the digestive tract of gastropods, which participates, together with the CNS, in the regulation of digestive functions. We succeeded to reveal 5-HT in juveniles by immunohistochemical methods only. The 5-HT-im elements involved in the innervation of the digestive system in C. laevis are much less numerous than CA-

Обозначения: cer.g. - церебральный ганглий; ped.g. — педальный ганглий; е — эпителий; n — нотум; nе нейрон; np - нейропиль; о - глаз; rc - рецепторные клетки; rh - ринофор; rspp - область глоточного сфинктера. Остальные обозначения см. на Рис. 1. Масштаб: А - 100 мкм; В-D - 50 мкм; Е - 15 мкм. 


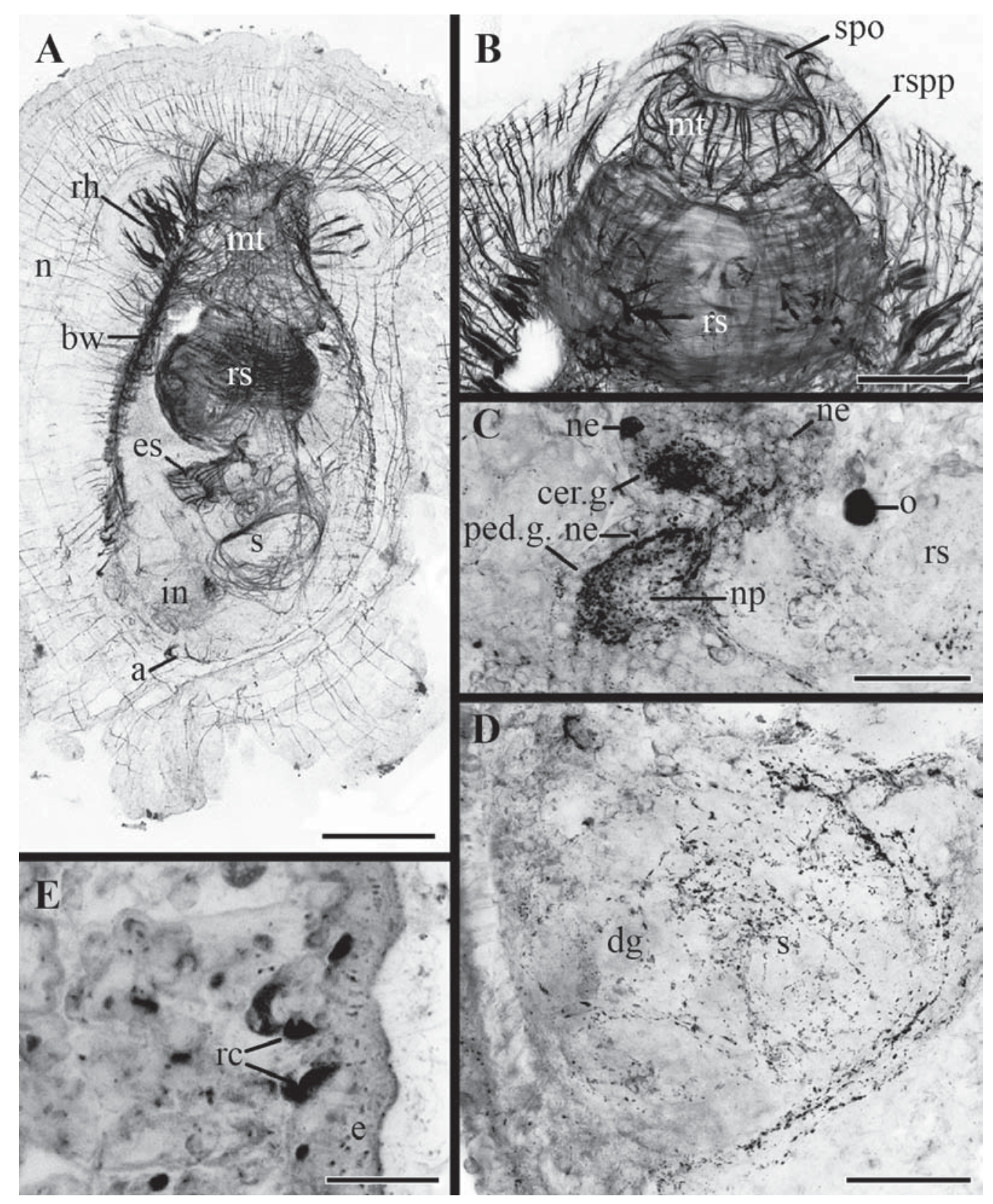

Fig. 2. Musculature (A-B) and localization of FMRFamide (C-E) in a juvenile C. laevis. Maximum intensity projections of series of confocal optical sections from whole-mount preparations. A, B, D - dorsal view; $\mathrm{C}$ - lateral view; E - ventral view.

Abbreviations: cer.g. — cerebral ganglion; ped.g. — pedal ganglion; e — epithelium; $\mathrm{n}$ - notum; ne - neuron; $\mathrm{np}-$ neuropil; o - eye; rc — receptor cells; rh — rhinophore; rspp — region of the pharyngeal sphincter. See Fig. 1 for other abbreviations. Scale bar: A $-100 \mu \mathrm{m} ; \mathrm{B}-\mathrm{D}-50 \mu \mathrm{m}$; E $-15 \mu \mathrm{m}$.

Рис. 2. Мускулатура (A-B) и локализция FMRFамида (C-E) у ювенильных C. laevis. Проекции максимальной интенсивности серий конфокальных оптических срезов тотальных препаратов. А, В, $\mathrm{D}$ - вид со спинной стороны; C — вид сбоку; Е — вид с брюшной стороны. 


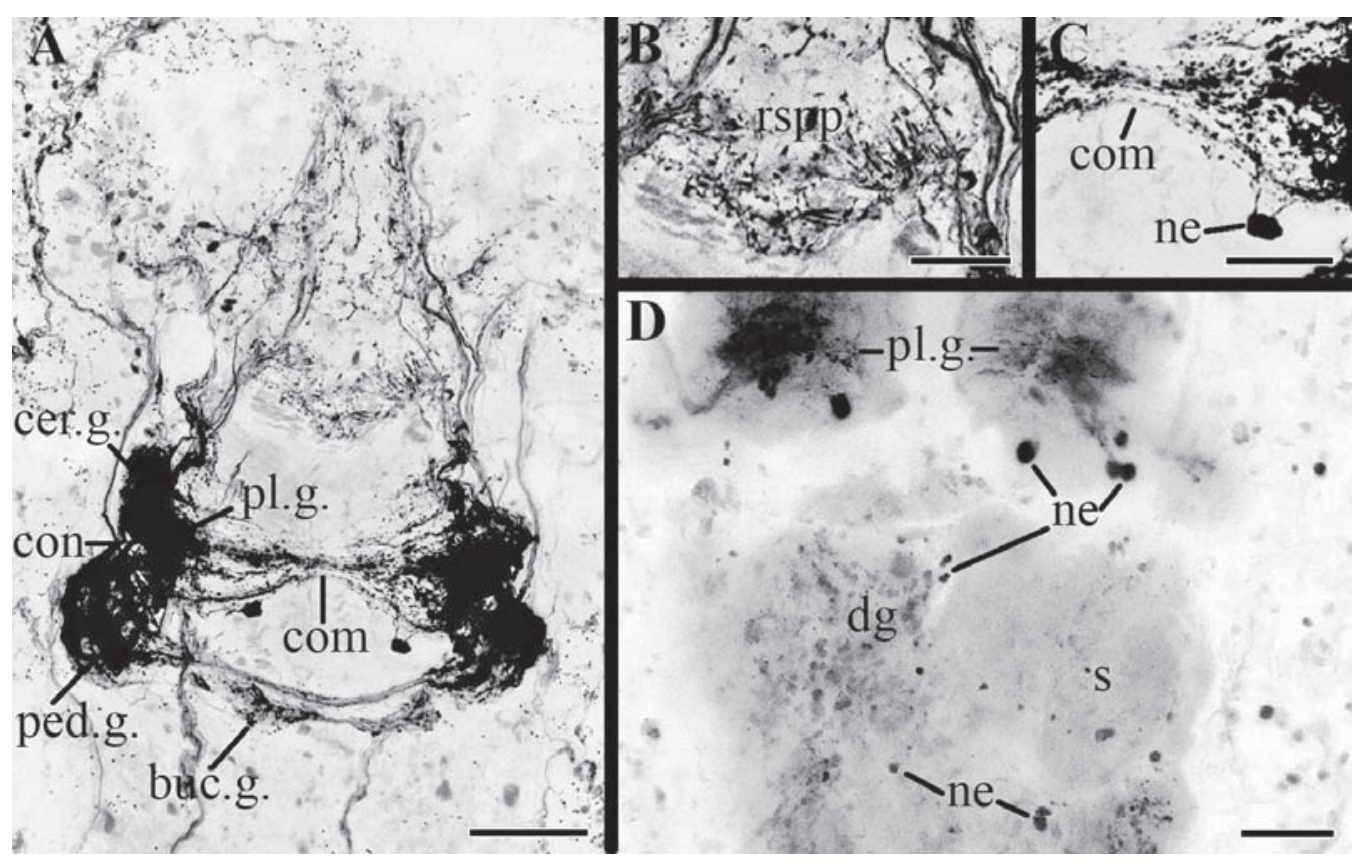

Fig. 3. Catecholamines in the nervous system of a juvenile $C$. laevis as revealed by GIF $(\mathrm{A}-\mathrm{C})$ or FaGlu (D) method. B and C are enlarged parts of the image A. A-D - dorsal view.

Abbreviations: buc.g. — buccal ganglion; com - commissure; con — connective; pl.g. — pleural ganglion. See Fig. 1 and 2 for other abbreviations. Scale bar: A $-50 \mu \mathrm{m}$; B-D $-25 \mu \mathrm{m}$.

Рис. 3. Катехоламины в нервной системе у ювенильных C. laevis, выявленные с помощью методов GIF (A-C) или FaGlu (D). В и C - увеличенные участки изображения A. A-D - вид со спинной стороны.

Обозначения: buc.g. — буккальный ганглий; com — комиссура; con — коннектива; pl.g. — плевральный ганглий. Остальные обозначения см. на Рис. 1 и 2. Масштаб: А -50 мкм; B-D - 25 мкм.

containing elements. A small number of 5-HTim neurons and neurites are found in the CNS ganglia. Efferent innervation of the radular sac and the mouth tube is observed. Thus, in juvenile $C$. laevis monoamines already take an active part in the regulation of the sensory functions, in the functioning of the musculature and the digestive system and can participate in the feeding behaviour, as it was shown for adult individuals of previously studied species of gastropods and other invertebrates (Quinlan et al., 1997; Croll, 2001; Markosova et al., 2007; Zaitseva, Petrov, 2013).

The digestive system of $C$. laevis is regulated by CA-containing and FMRFamide-im neurons located both in the CNS ganglia and directly in the wall of the digestive tract. The highest number of CA-containing and FMRFamide-im nervous elements was found in the wall of the pharynx, the stomach and the digestive gland. The 5-HT-im innervation was observed primarily in the pharyngeal region of the digestive system.

\section{Acknowledgments}

This study was performed as part of budget project AAAA-A17-117030110029-3 of the Zoological Institute of the Russian Academy of Sciences and supported by the Russian Foundation for Basic Research (project 15-29-02650). We thank A.V. Martynov (Zoological Museum of Moscow State University, Moscow, Russia) and T.A. Korshunova (Koltzov Institute of Developmental Biology RAS, Moscow, Russia), who kindly provided the hatchlings of $C$. laevis for this study. 


\section{References}

Bullock T.H., Horridge G.A. 1965. Structure and function in the nervous system of invertebrates. San Francisco, Calif.: W.H. Freeman. 1719 p.

Croll R.P. 2001. Catecholamine-containing cells in the central nervous system and periphery of Aplysia californica // J. Comp. Neurol. Vol.441. No.2. P.91-105.

De la Torre J.C., Surgeon J.W. 1976. A methodological approach to rapid and sensitive monoamine histofluorescence using a modified glyoxylic acid technique: the SPG method // Histochemistry. Vol.49. No.2. P.81-93.

Furness J.B., Costa M., Wilson A.J. 1977. Water-stable fluorophores, produced by reaction with aldehyde solutions, for the histochemical localization of catechol- and indolethylamines // Histochemistry. Vol.52. No.2. P.159-170.

Markosova T.G., Zaitseva O.V., Smirnov R.V. 2007. Monoamine- and peptide- containing elements in the nemertine digestive tract // J. Evolut. Biochem. Physiol. Vol.43. No.1. P.69-79.

Punin M.Yu. 2001. [Intestinal regulatory system of invertebrates and its possible evolution in Metazoa]. St.Petersburg: Izd. SPbGU. 165 p. [In Russian]

Quinlan E.M., Arnett B.C. 1997. Murphy A.D. Feeding stimulants activate an identified dopaminergic interneuron that induces the feeding motor program in Helisoma // J. Neurophysiol. Vol.78. No.2. P.812824.

Voronezhskaya E.E., Croll R.P. 2016. Mollusca: Gastropoda // A. Schmidt-Rhaesa, S. Harzsch, G. Purschke (eds.). Structure and evolution of invertebrate nervous systems. Oxford: Oxford University Press. P.196-221.

Voronezhskaya E.E., Hiripi L., Elekes K., Croll R.P. 1999. Development of catecholaminergic neurons in the pond snail, Lymnaea stagnalis: I. Embryonic development of dopamine-containing neurons and dopamine-dependent behaviors // J. Comp. Neurol. Vol.404. No.3. P.285-296.

Zaitseva O.V. 2006. Nerve cells in the digestive tract epithelium of Gastropods // Doklady Biological Sciences. Vol.408. P.220-222.
Zaitseva O.V. 2014. [Phylogeny of the regulatory systems of the digestive tract in representatives of invertebrate animals, principles of adaptive-compensatory mechanisms] // Valkovich E.I., Droblenkova A.V. (eds.). Aktual'nyie problemy morfologii: embrional'nyy i reparativnyy gistogenez, filogistogenez. K 100-letiyu so dnya rozhdeniya chl.-korr. AMN SSSR, professora A.G. Knorre. St. Petersburg: SPbGPMU. P.83-86 [in Russian].

Zaitseva O.V., Filimonova S.A. 2006. Nerve cell and nerve plexus ultrastructure in the digestive tract epithelium of Gastropoda // Doklady Biological Sciences. Vol.40. No.1. P.308-310.

Zaitseva O.V., Kuznetsova T.V. 2008. [Distribution of acetylcholinesterase activity in the digestive system of the gastropod mollusks Littorina littorea and Achatina fulica] // Morfologiia. Vol.133. No.1. P.55-59 [in Russian, with English summary].

Zaitseva O.V., Kuznetsova T.V., Markosova T.G. 2009. NADPH-diaphorase activity in the digestive system of gastropod mollusks Achatina fulica and Littorina littorea // J Evolut. Biochem. Physiol. Vol.45. No.1. P.110-121.

Zaitseva O.V., Markosova T.G. 2008. Acetylcholine, nitric oxide and their possible colocalization in regulatory cells of the digestive system of Gastropods // Doklady Biological Sciences. Vol.421. P.248-250.

Zaitseva O.V., Markosova T.G., Smirnov R.V., Soboleva V.V. 2004. Investigation of cell composition of the intestinal nervous system in Gastropods, Nemertins and Priapulids. Proc. Zool. Inst. Russ. Acad. Sci. St. Petersburg. Vol.300. P.171-180.

Zaitseva O.V., Petrov S.A. 2013. Biogenic amines in the nervous system of nemerteans // Doklady Biological Sciences, General Biology. Vol.451. P.228-230.

Zaitseva O.V., Shumeev A.N., Korshunova T.A., Martynov A.V. 2015. Heterochronies in the formation of the nervous and digestive systems in early postlarval development of opisthobranch mollusks: organization of major organ systems of the arctic dorid Cadlina laevis // Biology Bulletin. Vol.42. No.3. P.186-195.

Responsible editor E.N. Temereva 
